\title{
MAGMATIC ENCLAVES AND MAGMA MIXING IN MORNE MICOTRIN, DOMINICA
}

SARAH HICKERNELL, Union College

Research Advisor: Holli Frey

\section{INTRODUCTION}

Morne Micotrin in Dominica, Lesser Antilles is an andesitic lava dome located on the northeastern margin of the Wotten Waven caldera, an active geothermal area (Smith et al., 2013). Micotrin is comprised of two coalesced domes, formed within $3.5 \mathrm{~km}$ diameter craters. Located at the head of the $8 \mathrm{~km}$ Roseau Valley, Wotten Waven and Micotrin are the most likely source for the $\sim 3 \mathrm{~km}^{3}$ of pyroclastic deposits filling the valley (Sigurdsson, 1972). Dominica's capital city Roseau, with a population of 17,000 , sits at the bottom of this valley. A series of explosive eruptions formed the Roseau Sequence between 20 and $70 \mathrm{ka}$, with a $\sim 6$ ka deposit at Casso being the youngest dated (Howe et al., 2014; Frey et al., 2016). Block-and-ash flows from Micotrin near the top of the Roseau Sequence suggests that major period of dome growth occurred following explosive eruption (Smith et al., 2013). Micotrin last erupted explosively approximately $1 \mathrm{ka}$, and therefore poses a risk to the adjacent valley and island of Dominica as a whole (Lindsay et al., 2005). Shallow seismicity in Wotten Waven and volcanic earthquakes beneath Micotrin suggest that the magmatic system that initially formed Micotrin is still active at depth. Further, warm streams flowing down the dome's eastern flank stain their banks orange, suggesting geothermal springs may be feeding streams at higher elevations (Lindsay et al., 2005).

The presence of mafic enclaves has been documented in Dominica at several lava domes, and suggests that magma mixing and mingling processes at depth are shaping the evolution of the lava domes (Howe et al., 2015; Halama et al., 2006). Mafic enclaves, volumes of compositionally unique magma emplaced into a host, are evidence of mafic injection into a silicic system. Mafic injections introduce volatiles, heat, and pressure, and push the magmatic system out of equilibrium. Injections can therefore be eruption triggers, and by studying enclaves one can determine the extent of disequilibrium caused by mafic injection. Enclaves give insight into the nature of the mafic magma, and comparison to the host can allow one to reconstruct how the mafic magma impacted the silicic host. During the Soufriere Hills eruption in nearby Montserrat from 1995 until 2012, several types of mafic enclaves were documented in the host andesite, and their characteristics were studied to help reconstruct the nature of the magma chamber, and the ultimate source feeding the eruption (Plail et al., 2014; Barclay et al., 2010; Mann et al., 2010). Additionally, the increase in abundance of mafic enclaves has been correlated to an increase in intensity of the eruption event, supporting the idea that injections at depth are keeping the system active (Barclay et al., 2010). Considering its geographic proximity to Dominica and the ability to continuously monitor this modern eruption, Soufriere Hills serves as a functional analog for the magmatic systems beneath Dominica.

Through this study, we aim to better understand the magmatic system beneath Dominica and understand eruption triggers by characterizing the mafic enclaves found in the host rock of Morne Micotrin. Two main types of enclaves, coarse-grained and fine-grained, can be found in Micotrin, and these enclave types differ significantly from the host rock as well as from one another. Relatively large-scale characteristics, including mineral assemblage, vesicles, boundaries, and reactions, as well as finer-scale characteristics, including individual mineral zoning and whole rock, 
phenocryst, and glass compositions, have been thoroughly examined to help determine the nature of the differing magmas.

\section{METHODS}

We sampled a quarry on the western flank of Micotrin, based on the availability of relatively fresh, unweathered rock and abundance of enclaves observed at this site during past visits. Several samples of each enclave type were collected to determine the extent of variability amongst enclaves.

Following fieldwork, sample preparation was conducted at Union College in Schenectady, NY. After cutting down the samples, rock powders were made by placing the samples into a hydraulic press and then powdered by agitation in a Spex $15 \mathrm{~cm}$ aluminum oxide puck mill. The powders were sent to Acme Labs in Vancouver, Canada for ICP-OES analysis of major elements. Trace elements were analyzed at Union College on an ICP-MS using $200 \mathrm{mg}$ powdered samples. The powders were dissolved and analyzed by the procedure outlined in Hollocher et al. (2007). The major element compositions of plagioclase, pyroxenes, oxides, and glass were analyzed with a Zeiss EVO MA15 using energy-dispersive spectroscopy (EDS). Back-scattered electron (BSE) imagery was utilized to image and observe zonation patterns in individual phenocrysts, whereas EDS was utilized for quantitative analyses. Pyroxenes and oxides were analyzed using a 5 um beam spot. Oxides were standardized on spinel for $\mathrm{Mg}$ and $\mathrm{Al}$, rutile for $\mathrm{Ti}$, hematite for $\mathrm{Fe}$, and spessartine for $\mathrm{Si}, \mathrm{Ca}$, and $\mathrm{Mn}$. For plagioclase, we used a $100 \mu \mathrm{m}$ rastered beam and standardized on PX69 for $\mathrm{Mg}$ and $\mathrm{Si}$, GKFS for $\mathrm{K}$, amilia albite for $\mathrm{Na}$, and grossular for $\mathrm{Al}$ and $\mathrm{Ca}$. Pyroxenes were standardized on grossular for $\mathrm{Al}$ and $\mathrm{Ca}, \mathrm{PX} 69$ for $\mathrm{Si}$ and $\mathrm{Mg}$, hede for Fe and $\mathrm{Mn}$, acmite for $\mathrm{Na}$, and GKFS for K.

To calculate melt temperatures, we used all possible pairs of Fe-Ti oxides and the geothermometer of Ghiorso and Evans (2008). To determine water content we utilized a plagioclase hygrometer, which requires the input of the average melt temperature, whole melt/rock composition, and highest anorthite content plagioclase (Waters and Lange, 2015).

\section{RESULTS}

\section{Petrography}

Mineral abundances were determined by point counting five different enclaves (500-1000 points, depending on enclave size). Fine-grained enclaves contain $50.6 \%$ plagioclase, $10.9 \%$ opx, $6.6 \% \mathrm{cpx}$, $6.8 \%$ oxides, $5.3 \%$ quartz, $17.2 \%$ vesicles, and $2.5 \%$ microlites. Coarse-grained enclaves contain 52.5\% plagioclase, $10.7 \%$ opx, $0.5 \% \mathrm{cpx}, 8.4 \%$ oxides, $2.2 \%$ quartz, $13.7 \%$ vesicles, and $11.8 \%$ microlites. Finegrained enclave pyroxenes tend to grow outward from inner nucleation points, and average 0.01-0.02 $\mathrm{cm}$. Fine-grained enclave plagioclase average 0.05 , with larger phenocrysts up to $0.1 \mathrm{~cm}$. Coarse-grained enclave pyroxenes tend average $0.05 \mathrm{~cm}$ in size, whereas plagioclase average $0.1 \mathrm{~cm}$.

Fine-grained enclave boundaries are quite distinct. The host contains a relatively dark, fine-grained matrix that is absent in the enclaves. Coarse-grained enclave boundaries can be sharp to diffuse, which may be due in part to the large size of the phenocrysts obscuring the transition. Both enclave types are more vesicular than the host, however the coarse-grained enclaves tend to be notably more vesicular than the fine-grained enclaves (Figure 1). It does not appear that there is extensive transfer of material between the enclaves and the host based on observation of phenocryst textures.
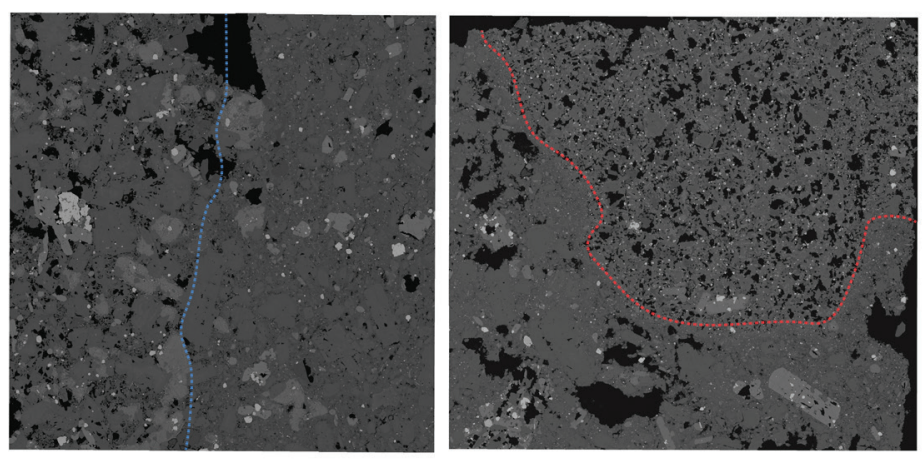

Figure 1. Back-scattered electron maps of a coarse-grained enclave (left) and fine-grained enclave (right). The dotted lines indicate the boundaries between enclave and host. Note the high vesicularity and lack of matrix in the enclaves. Coarse-grained enclave field of view $\sim 1 \mathrm{~cm}$, fine-grained enclave field of view $\sim 1.3 \mathrm{~cm}$. 

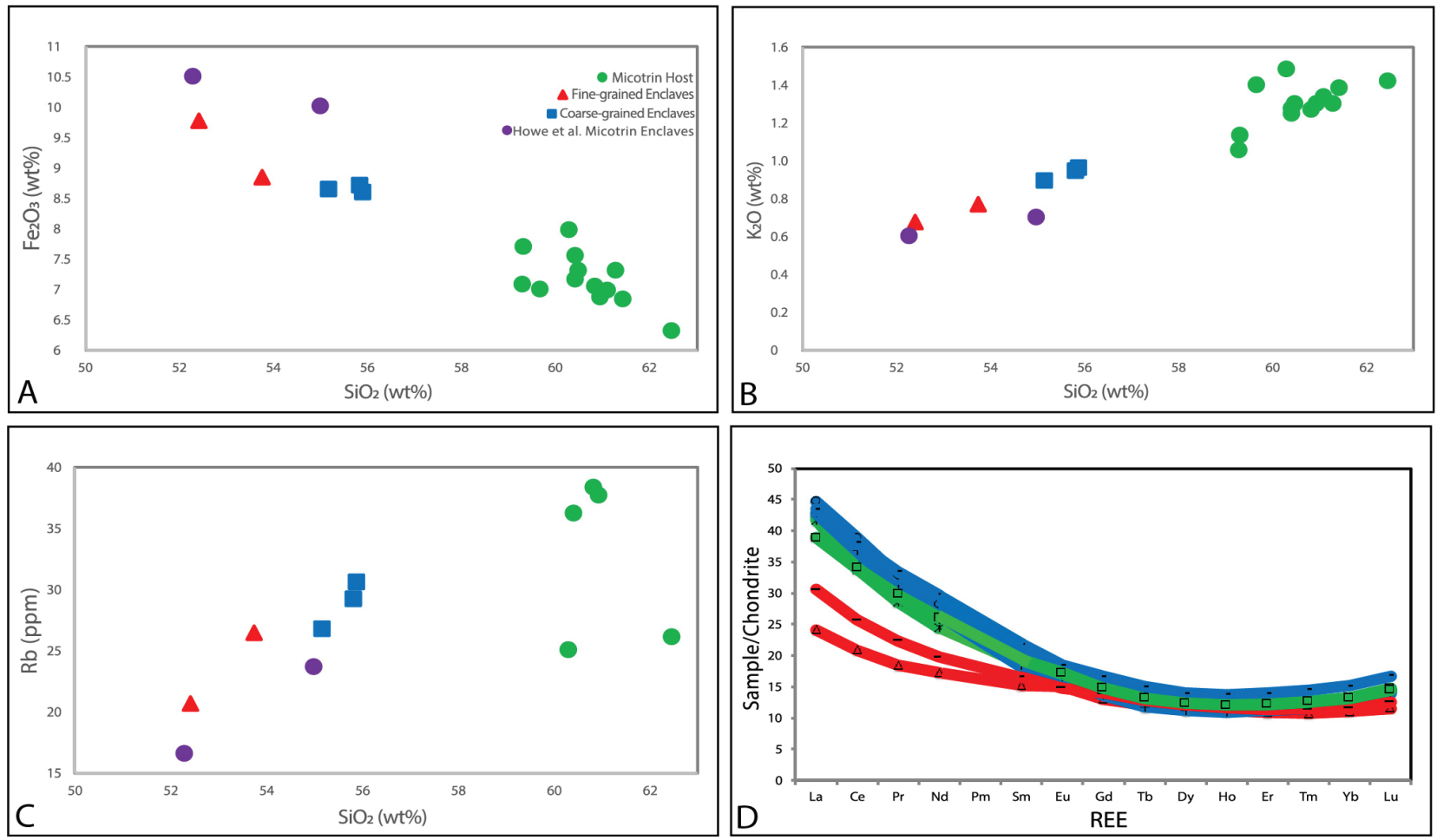

Figure 2. Morne Micotrin whole rock geochemistry. Major elements (A and B), trace elements $(C)$ and rare earth elements $(D)$ were analyzed to determine compositional differences between the two enclave types and the host.

\section{Bulk Chemistry}

Major element analysis reveals that both the finegrained enclaves $\left(52-54 \mathrm{wt} \% \mathrm{SiO}_{2}\right)$ and the coarsegrained enclaves $\left(55-56 \mathrm{wt} \% \mathrm{SiO}_{2}\right)$ are more mafic than the host andesite (59-62 wt\% $\left.\mathrm{SiO}_{2}\right)$. Enclaves are relatively enriched in $\mathrm{Fe}, \mathrm{Mg}$, and $\mathrm{Ca}$. The enclaves are relatively depleted in $\mathrm{K}$. Al and $\mathrm{Na}$ abundances are comparable across both enclaves and the host. The fine-grained enclaves differ most compositionally from the host, with the coarse-grained enclaves tending to plot as an intermediate (Figure 2).

The enclaves are depleted in some trace elements compared to the host, including $\mathrm{Rb}, \mathrm{Ba}$, and $\mathrm{Sr}$. Other elements, including $\mathrm{Zr}$, show little to no difference in concentration across the enclave types and host (Figure 2).

Rare earth element concentrations relative to chondrite were plotted to determine possible genetic relationships between the enclaves and the host. The coarse-grained enclaves' and host's trends are nearly parallel, whereas the fine-grained enclaves' trend dips in the light REE (Figure 2).

\section{Plagioclase}

Plagioclase phenocrysts in the host, as well as the enclaves, exhibit dark rims of grainy-looking, very small inclusions. In some samples, this texture occurs in rims around the core of the phenocryst, whereas in others this texture is extensive throughout the crystal. Under BSE, this texture appears to be inclusions or reaction phases that are too small for individual analysis.

Plagioclase phenocrysts in coarse-grained enclaves are normally- and reversely-zoned, and range from approximately $\mathrm{An}_{45-88}$ with some outliers (Figure 3). Several plagioclase rims in coarse-grained enclaves have a potassic component, up to 10 weight $\%$ orthoclase (Figure 4). Fine-grained enclave plagioclase phenocrysts also appear both normally- and reverselyzoned, and range from $\mathrm{An}_{48-94}$ (Figure 3). Some plagioclase rims were quite potassic in the fine-grained enclaves, up to 42 weight $\%$ orthoclase (Figure 4 ). The host plagioclase is normally- and reversely-zoned and has comparable average anorthite compositions, however the host lacks orthoclase rims. Additionally, the host plagioclase has lower maximum anorthite content (An77) than both enclave types (Figure 4). 

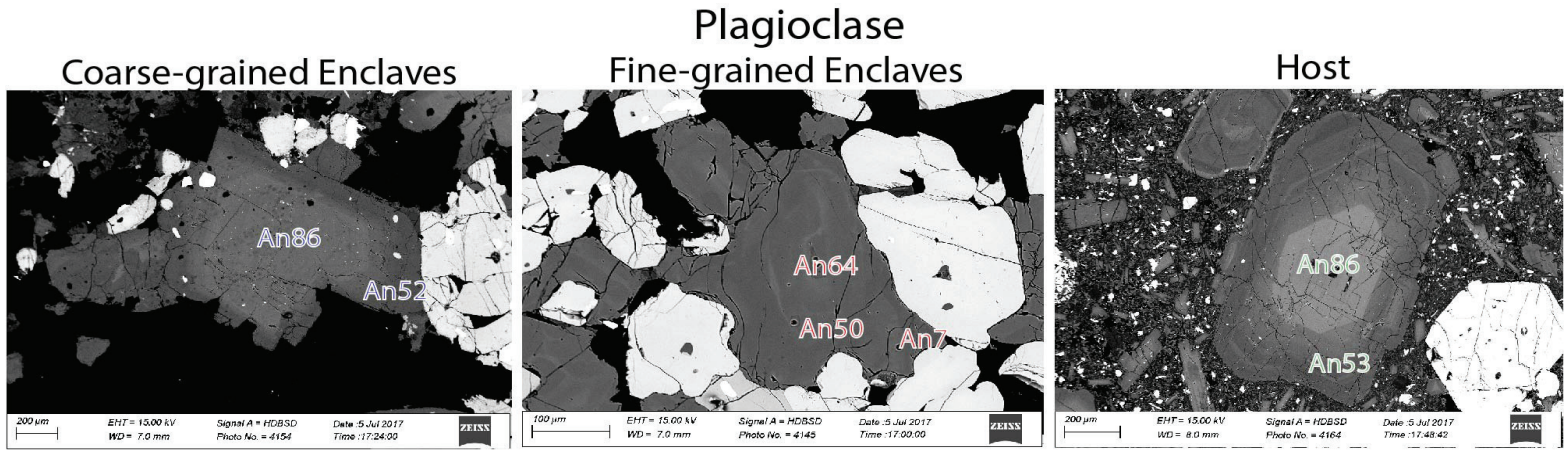

Coarse-grained Enclaves

\section{Pyroxene}

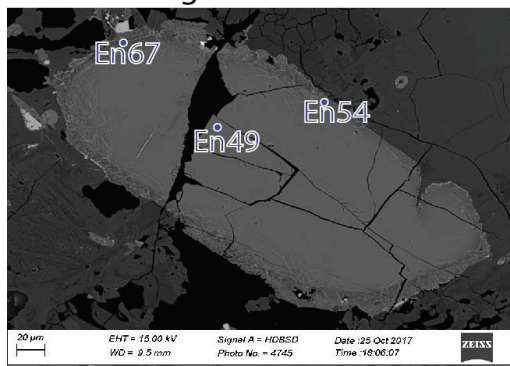

Fine-grained Enclaves
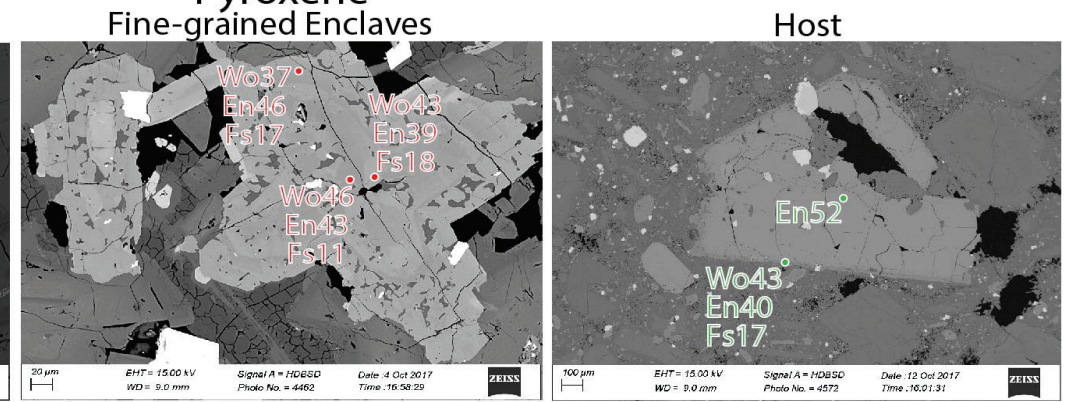

Oxides

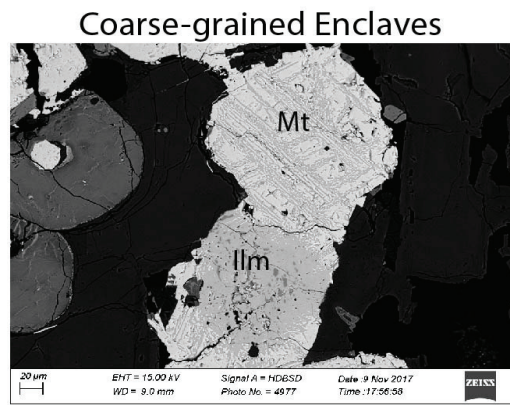

Fine-grained Enclaves

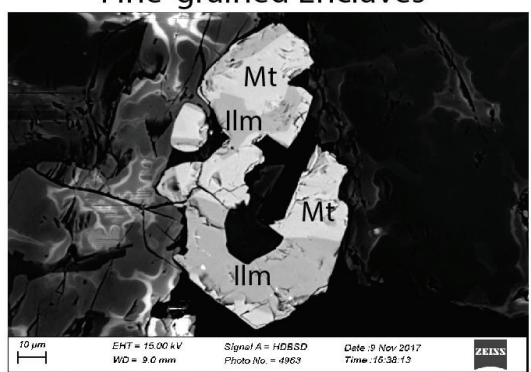

Figure 3. Characteristic back-scattered electron images of typical phases in each enclave type and the host showing zoning and example compositions.

\section{Pyroxene}

Pyroxene in the host is reversely- and normally-zoned, with compositionally distinct cores and rims. Both enclave types are more complex, with frequent patchy and oscillatory zoning throughout the pyroxene phenocrysts (Figure 3). Clinopyroxene is quite scarce in coarse-grained enclaves, occurring primarily as rims on orthopyroxenes. Mg-rich rims are abundant in both enclave types, as phenocrysts are commonly reversely zoned. Fine-grained enclave pyroxene cores tend to be Ca-enriched relative to coarse-grained enclave pyroxenes, and clinopyroxene is much more abundant in fine-grained enclaves than in coarse-grained. $\mathrm{Mg}$ rich rims are common in fine-grained enclaves as well, however Fe-rich rims also occur (Figure 5). The host pyroxene compositions are relatively tightly clustered relative to the enclaves, and have similar compositional ranges to the enclaves $\left(\operatorname{En}_{50-70}\right)($ Figure 5).

\section{Oxides}

Oxides in both enclave types occur as magnetite and ilmenite, and are relatively titanium-enriched. The enclave oxides are highly exsolved, particularly in the coarse-grained enclaves (Figure 3). Oxides occur as independent phases as well as inclusions, particularly in pyroxenes. The high degree of exsolution in the enclave oxides led to a relatively high degree of analytical uncertainty. In comparison, the host oxides are far less exsolved and yield more reliable analyses. 

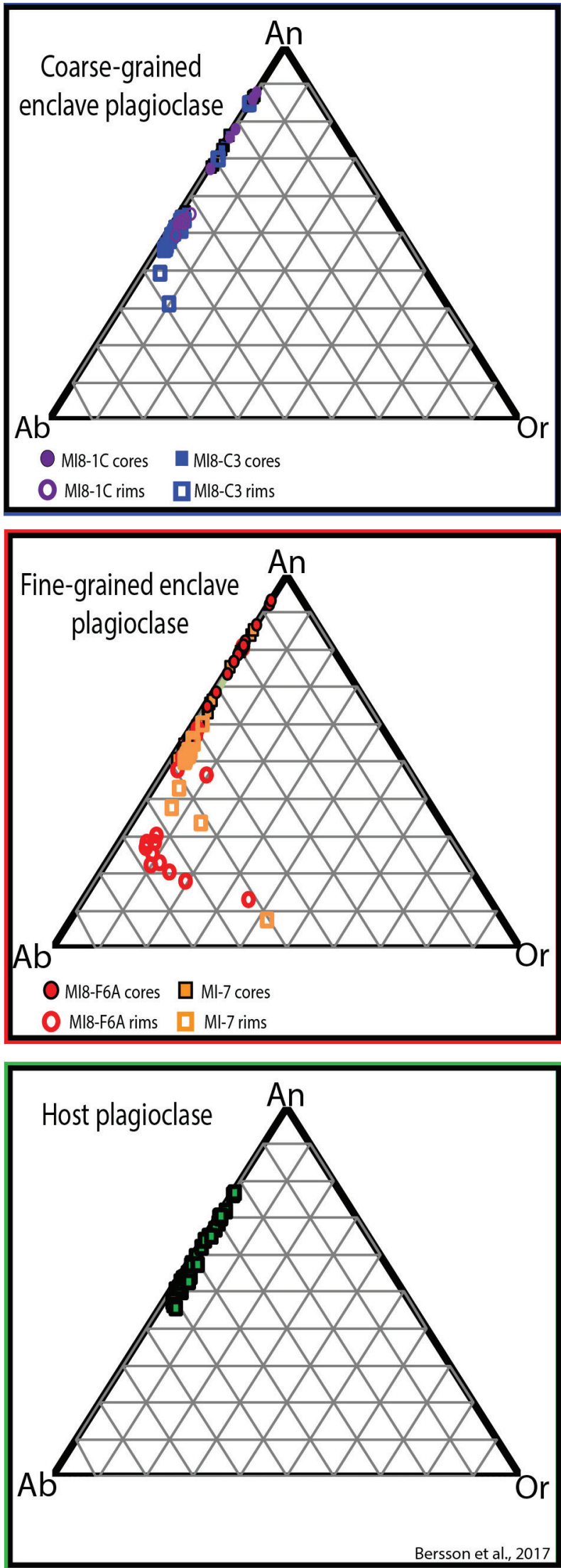

Figure 4. Plagioclase ternaries for feldspar phenocrysts analyzed in both enclave types and the host. Note the lack of potassiumrich analyses in the host relative to the enclaves.
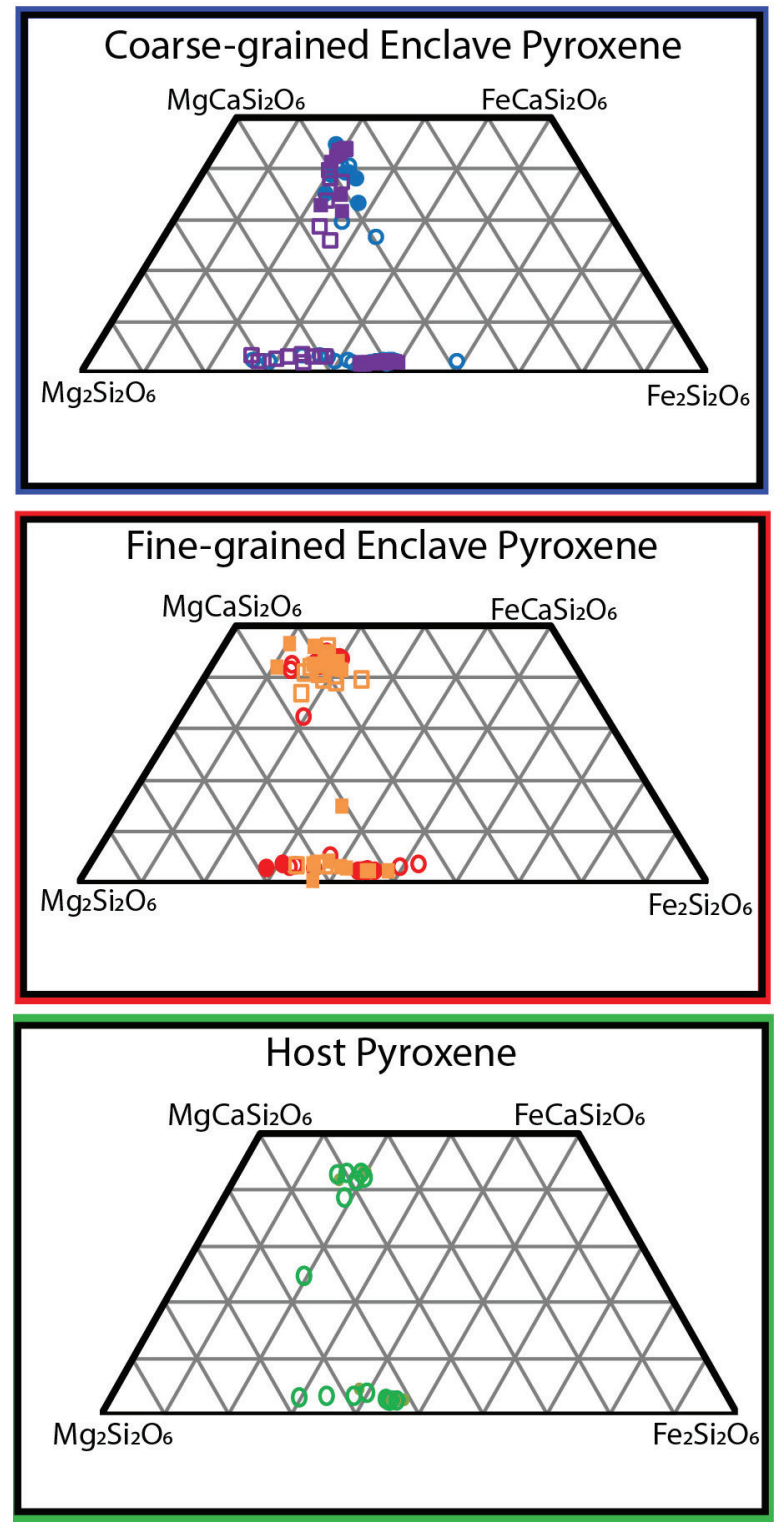

Figure 5. Pyroxene quadrilaterals for pyroxene phenocrysts analyzed in both enclave types and the host. Note the Mg-rich rims and the wide spread in the enclave data relative to the host.

\section{Calculation of Intensive variables: Geothermom- etry and Hygrometer}

Magnetite and ilmenite were targeted in both enclave types and the host to employ a two-oxide geothermometer (Ghiorso and Evans, 2008) for reconstruction of melt temperatures and oxygen fugacity. The coarsegrained enclaves yield temperatures of $890 \pm 91{ }^{\circ} \mathrm{C}$ and $774 \pm 168^{\circ} \mathrm{C}$. Coarse-grained enclaves yield $\mathrm{fO}_{2}$ values of $1.00 \pm 0.23$ and $1.49 \pm 1.22$ relative to $\triangle$ NNO. Fine-grained enclaves yield temperatures of $891 \pm$ $74^{\circ} \mathrm{C}$ and $794 \pm 60^{\circ} \mathrm{C}$, and $\mathrm{fO}_{2}$ values of $0.42 \pm 0.23$ and $0.60 \pm 0.21$ relative to $\triangle \mathrm{NNO}$. In comparison, the 
host oxides yield a temperature of $851 \pm 24^{\circ} \mathrm{C}$ and average $\mathrm{fO}_{2}$ of $0.30 \pm 0.15$ relative to $\triangle \mathrm{NNO}$ (Bersson et al., 2018).

Based on the highest anorthite plagioclase in each sample type, a plagioclase hygrometer was utilized to determine the water content of the melt. Coarsegrained enclaves contain up to 10 weight $\% \mathrm{H}_{2} \mathrm{O}$ and fine-grained enclaves contain up to 9.7 weight $\% \mathrm{H}_{2} \mathrm{O}$, whereas the host contains up to 6.4 weight $\% \mathrm{H}_{2} \mathrm{O}$ (Waters and Lange, 2015).

\section{DISCUSSION}

Major element analysis of both enclave types and the host reveals that the enclaves differ compositionally from the host andesite in several major and trace elements. Major element compositions tend to have linear trends, with the fine-grained enclaves being most dissimilar from the host (Figure 2). Enclave compositions are also comparable to enclaves analyzed from other volcanic centers on Dominica (Howe et al., 2015; Halama et al., 2006). When comparing REE to chondrite, we find that coarse-grained enclaves and the host plot similarly, suggesting a process such as fractional crystallization could account for the differences observed (Figure 2). However, the finegrained enclaves' plot is not parallel to the host and coarse-grained enclave. This suggests that another mechanism must be considered to account for the finegrained enclaves, such as a higher degree of partial melt. Fractional crystallization alone cannot account for the trend differences observed.

The plagioclase compositions from both enclave types to the host is comparable $\left(\mathrm{An}_{45}-\mathrm{An}_{80}\right)$, however the compositions in the enclaves reach higher anorthite contents than the host (up to $\mathrm{An}_{94}$ ). Additionally, the potassic rims observed in the enclaves is absent in the host (Figure 4). The trend of the feldspar compositions in each enclave type generally follows the plagioclase solvus. This suggests that the enclaves may have a unique thermal history relative to the host. The enclave plagioclase was in a melt for a longer period of time than the host, allowing $\mathrm{K}$ into the crystal structure. Therefore, the source of the enclaves and their melt may be unique relative to the host as well. Further, both enclave types have higher water content than the host based on plagioclase hygrometery
(Waters and Lange, 2015). The higher water content in the enclaves suggests that when a mafic injection occurred, forming these enclaves, it also introduced a greater concentration of water. Water is an important volatile in volcanic systems, and its introduction may have caused unrest in Micotrin and potentially triggered eruption.

Pyroxene rims in both enclave types are Mg-rich, and the reverse zoning commonly observed may be insight into how mafic injections changed the melt in Micotrin over time. Injections would have introduced more magnesium into the system, which could then be preferentially incorporated into pyroxene rims. This trend is observed in the host as well, but to a lesser degree. Further, the cpx compositions in the enclave vary widely, with $20 \%$ wollastonite variation (Figure 5). The host is more tightly-clustered in comparison. This suggests that the enclaves may have been experiencing changing melt conditions over time, whereas the host melt was relatively consistent.

The temperatures obtained from two oxide geothermometry have a high level of error associated with them, and therefore a more robust estimate on the temperatures of both enclave types' melts is desirable. However, based on $\mathrm{fO}_{2}$ data, it appears that weathering and oxidation plays a greater role in the enclave oxides and their exsolution than in the host.

Based on the data compiled in this study, it is apparent that the enclaves have a unique history relative to the host. The fine-grained enclaves cannot be related to the coarse-grained enclaves or the host by fractional crystallization alone, and supports an open-system model of the magma chamber underlying Morne Micotrin. Additionally, potassic plagioclase rims in both enclave types suggests that both enclave types have undergone heating and dynamic magma chamber conditions to a greater degree than the host. The heating that the enclaves experienced may have reinvigorated the magma chamber beneath Micotrin as well, and resulted in a period of volcanic unrest from Micotrin or Wotten Waven. By better understanding how enclaves have formed and how they differ from the host, we can better model the larger magmatic system at depth and explain possible sources of eruptive episodes. 


\section{ACKNOWLEDGEMENTS}

This material is based upon work supported by the Keck Geology Consortium and the National Science Foundation under Grant No. 1659322. Thanks to Holli Frey, Matt Manon, and Laura Waters for their guidance and advice throughout my research experience, and thanks to the other Keck researchers on this project for help in the field.

\section{REFERENCES}

Barclay, J., Herd, R.A., Edwards, B.R., Christopher, T., Kiddle, E.J., Plail, M, and Donovon, A. (2010). Caught in the act: Implications for the increasing abundance of mafic enclaves during the recent eruptive episodes of the Soufriere Hills Volcano, Montserrat. Geophysical Research Letters, 37.

Bersson, J.J., Waters, L.E., Frey, H.M., Nicolaysen, K.P., and Manon, M.R.F. (2017). Explosive to Effuse Transition in Intermediate Volcanism: An Analysis of Changing Magma System Conditions in Dominica. 2017 American Geophysical Union Fall Meeting, V43A-0516.

Frey, H. M., Manon, M.R.F., Brehm, S., and Babiak, R.N. (2016). U-Th zircon chronology reveals protracted cold storage and subsequent rejuvenation in magma reservoirs beneath Dominica, Lesser Antilles. 2016 American Geophysical Union Fall Meeting, V53D-3157. Ghiorso, M.S., and Evans, B.W. (2008).

Thermodynamics of rhombahedral oxide solid solutions and a revision of the Fe-Ti twooxide geothermometer and oxygen-barometer. American Journal of Science, 308: 957-1039.

Halama, R., Boudon, G., Villemant, B., Joron, J.-L., Le Friant, A., and Komorowski, J.-C. (2006). Pre-eruptive crystallization conditions of mafic and silicic magmas at the Plat Pays volcanic complex, Dominica (Lesser Antilles). Journal of Volcanology and Geothermal Research, 153: 200-220.

Hollocher, K., Robinson, P., Terry, M.P., and Walsh, E. (2007). Application of major- and trace-element geochemistry to refine $\mathrm{U}-\mathrm{Pb}$ zircon, and $\mathrm{Sm} / \mathrm{Nd}$ or $\mathrm{Lu} / \mathrm{Hf}$ sampling targets for geochronology of HP and UHP eclogites, Western Gneiss Region, Norway. American Mineralogist, 92: 1919-1924.
Howe, T.M., Lindsay, J.M., and Shane, P. (2015). Evolution of young andesitic-dacitic magmatic systems beneath Dominica, Lesser Antilles. Journal of Volcanology and Geothermal Research, 297: 69-88.

Lindsay, J.M., Smith, A.L., Roobol, M.J., and Stasiuk, M.V. (2005). Volcanic Hazard Atlas of the Lesser Antilles: Dominica. Seismic Research Unit, University of the West Indies.

Mann, C.P. (2010). Magma chamber dynamics at Soufriere Hills volcano, Montserrat. $\mathrm{PhD}$ thesis.

Plail, M., Barclay, J., Humphreys, M.C.S., Edmonds, M., Herd, R.A., and Christopher, T.E. (2014). Characterization of mafic enclaves in the erupted products of Soufriere Hills Volcano, Montserrat, 2009 to 2010. Geological Society of London Memoirs, 39: 343-360.

Sigurdsson, H. (1972). Partly-welded pyroclast flow deposits in Dominica, Lesser Antilles. Bulletin of Volcanology, 36: 148-163.

Smith, A.L., Roobol, M.J., Matioli, G.S., Fryxell, J.E., Daly, G.E., and Fernandez, L.A. (2013). The Volcanic Geology of the Mid-Arc Island of Dominica. Geological Society of America Special Paper, 496.

Waters, L.E., and Lange, R.A. (2015). An updated calibration of the plagioclase-liquid hygrometerthermometer applicable to basalts through rhyolites. American Mineralogist, 100: 21722184. 